\title{
Production of dihydroxyacetone from an aqueous solution of glycerol in the reaction catalyzed by an immobilized cell preparation of acetic acid bacteria Gluconobacter oxydans ATCC 621
}

\author{
Stasiak-Różańska Lidia • Błażejak Stanisław
}

Received: 18 July 2012/Revised: 19 September 2012/Accepted: 24 September 2012/Published online: 9 October 2012

(C) The Author(s) 2012. This article is published with open access at Springerlink.com

\begin{abstract}
Dihydroxyacetone (1,3-dihydroxy-2-propanone, DHA) is applied in the food and cosmetic industries as well as in pharmacy and medicine. It is produced as a result of incomplete oxidation of glycerol by acetic acid bacteria Gluconobacter oxydans. This reaction is catalyzed by PQQ-dependent membrane-bound glycerol dehydrogenase. The research developed a method of obtaining DHA by oxidation of a $3 \%$ aqueous solution of glycerol ( $\mathrm{pH} 7.5)$ at a temperature of $23{ }^{\circ} \mathrm{C}$, with the only reaction biocatalyst being an immobilized cell preparation obtained from G. oxydans cells. After 5 days of the process, DHA concentration in the solution accounted for $27.2 \mathrm{~g} / \mathrm{L}$ and the reaction efficiency for $94 \%$. After 4 days of the reaction run in culture media with $\mathrm{pH} 5.0$, at a temperature of $28^{\circ} \mathrm{C}$, free or immobilized cells of $G$. oxydans produced on average $25 \mathrm{~g}$ of DHA/L at the reaction efficiency of $87 \%$.
\end{abstract}

Keywords Glycerol · Dihydroxyacetone · Cell preparation - Glycerol dehydrogenase . Gluconobacter oxydans · Immobilization

$\begin{array}{ll}\text { Abbreviations } \\ \text { 3,5-DNS } & \text { 3,5-dinitrosalicylic acid } \\ \text { DHA } & \text { Dihydroxyacetone } \\ \text { G.oxydans } & \text { Gluconobacter oxydans ATCC } 621 \\ \text { GlyDH } & \text { Glycerol dehydrogenase } \\ \text { PQQ } & \text { Pyrroloquinoline quinone }\end{array}$

S.-R. Lidia $(\square) \cdot$ B. Stanisław Department of Biotechnology, Microbiology and Food Evaluation, Faculty of Food Sciences, Warsaw University of Life Sciences, Nowoursynowska St. 159 c, Warsaw, Poland e-mail: lidia_stasiak@sggw.pl

\section{Introductory remarks}

The dihydroxyacetone (DHA) has various uses in cosmetics $[5,10,16,31]$, medicine $[8,17,30]$, pharmaceuticals [12] and food industries [24, 26, 34]. Its production from glycerol is financial interesting due to the overproduction of glycerol by the biodiesel industry.

There are known two methods of dihydroxyacetone production: chemical and microbiological one [16]. The chemical synthesis may proceed via catalytic oxidation of glycerol or its condensation with calcium carbonate [13, 28].

An alternative to the chemical synthesis of DHA is microbiological oxidation of glycerol by microorganisms, acetic acid bacteria in particular, that exhibit a high activity of glycerol dehydrogenase $[9,36]$.

Glycerol dehydrogenase (GlyDH, EC 1.1.99.22) determines the incomplete oxidation of glycerol to DHA by acetic acid bacteria. This enzyme is strongly bound with the cytoplasmic membrane of acetic acid bacteria [32], and its oxidative activity is independent of NAD presence. The active center of GlyDH is located in the periplasmic space, which enables lesser consumption of energy required for the transport of substrates into and products outside the cell $[12,24,29]$. Due to a strongly hydrophobic character and low stability of the purified fraction of GlyDH, it is difficult to determine the spatial structure of this enzyme [20, 22, 23]. The optimal activity of GlyDH obtaining from cells of acetic acid bacteria of the genus Gluconobacter is observed in the $\mathrm{pH}$ range of 7.0-8.0 $[4,20]$ and in the temperature range of $23-25{ }^{\circ} \mathrm{C}$ [1].

Dihydroxyacetone production can be improved by GlyDH overexpression in Gluconobacter oxydans M5AM [21] In this study, the gene-coding membrane-bound alcohol dehydrogenase (ADH) was interrupted. The absence of $\mathrm{ADH}$ together with the overexpression of 
GlyDH gene resulted in an increased GlyDH activity in the strain M5AM/GlyDH, which led to a substantially enhanced production of DHA in the resting cells. In I batch of biotransformation process, G. oxydans M5AM/GlyDH exhibited a 2.4-fold increased DHA productivity of $2.4 \mathrm{~g} / \mathrm{g}$ $\mathrm{CDW} / \mathrm{h}$ (CDW-cell dry weight) from $1.0 \mathrm{~g} / \mathrm{g} \mathrm{CDW} / \mathrm{h}$, yielding $96 \mathrm{~g} / \mathrm{L}$ DHA from $100 \mathrm{~g} / \mathrm{L}$ glycerol. In four repeated batch runs, $385 \mathrm{~g}$ of DHA over a time period of $34 \mathrm{~h}$ was achieved from $400 \mathrm{~g}$ glycerol with an average productivity of $2.2 \mathrm{~g} / \mathrm{g} \mathrm{CDW} / \mathrm{h}$. This study indicated that new mutant $G$. oxydans M5AM/GlyDH with high productivity and increased tolerance against product inhibition has potential for DHA production in a industrial bioconversions process [21] Another microbial method of improving production of DHA by $G$. oxydans consisted of a semi-continuous repeated-fed-batch process by in situ immobilization of G. oxydans cells [15] In this experiment, a novel carrier material was used. Advantages of the new carrier matrix were as follows: ample space for the settling of cells, the protection of the cells from abrasion caused by shear forces or a sufficiently high oxygen supply rate due to the high oxygen permeability of the utilized silicone matrix. The experiment was conducted using packed-bed bubble-column bioreactor. The experimental results indicate that the immobilized biomass amounted to approximately $65 \%$ of the total biomass contained in the bioreactor after 18 days of operation. The space-time yield was approximately $76 \%$ higher compared to a similar process which was performed without an optimized fermentation medium [15]. Other experiments [25] to increase the microbial production of DHA included expression of three various genes which encode GlyDH (e.g., from Hansenula polymorpha). The $\mathrm{NAD}^{+}$-dependent GlyDH of $H$. polymorpha showed the highest glycerol-oxidizing activity. DHA concentration in shake flask experiments was roughly $100 \mathrm{mg} / \mathrm{L}$ from $20 \mathrm{~g} / \mathrm{L}$ glucose, that is, five times the wild-type level. This level was achieved only when cultures were subjected to osmotic stress known to enhance glycerol production and accumulation in Saccharomyces cerevisiae. Dihydroxyacetone kinase activity was abolished to prevent conversion of DHA to dihydroxyacetone phosphate. The double-deletion mutant overexpressing $H$. polymorpha GlyDH produced $700 \mathrm{mg} \mathrm{DHA} /$ $\mathrm{L}$ under the same conditions [25].

One of the main problems in the biotechnological production of DHA is a multistage process of acetic acid bacteria preparation that involves, that is, proliferation of these microorganisms in culture media (diversified in terms of the source of carbon and nutrients) and activation of GlyDH. The course of this reaction may be disturbed by the inhibiting effect of a glycerol substrate or/and the product formed on the metabolic activity of acetic acid bacteria and activity of GlyDH [9, 22, 24]. Apart from DHA, the post- reaction mixture contains other bacterial metabolites that impede purification and crystallization of DHA [6].

Our approach was the advantage that allows the production of DHA in reaction which is independent from the presence and metabolic activity of live cells of G. oxydans. Our method of biotransformation of glycerol to DHA allows to shorten the process of preparation of the biocatalyst (which is cell preparation), and additionally the production of DHA is carried out with the immobilized biocatalyst which can be easily separated from the reaction mixture and reused in the next cycle of reaction. The proposed method is novel due to the replacement of live cells of $G$. oxydans with an immobilized cell preparation with the activity of GlyDH and production media-with aqueous solutions of glycerol. This method will probably facilitate and accelerate the crystallization of the final product because the post-reaction media contains only DHA and residues of glycerol.

\section{Materials and methods}

\section{Strain and culture conditions}

The study was carried out with the strain of acetic acid bacteria G. oxydans ATCC 621 from American Type Culture Collection, University Boulevard, Manassas. The strain was passaged every 30 days onto the culture medium containing: yeast extract $5 \mathrm{~g} / \mathrm{L}$, peptone $3 \mathrm{~g} / \mathrm{L}$, mannitol $25 \mathrm{~g} / \mathrm{L}$ and agar $15 \mathrm{~g} / \mathrm{L}$, and incubated at a temperature of $28{ }^{\circ} \mathrm{C}$ for $24 \mathrm{~h}$. For biomass proliferation, a pure culture of G. oxydans was transferred to a $50 \mathrm{~cm}^{3}$ liquid medium containing yeast extract $30 \mathrm{~g} / \mathrm{L}$ (BTL) and ethyl alcohol $20 \mathrm{~cm}^{3} / \mathrm{L}(\mathrm{POCH})$, at $\mathrm{pH} 5.0$, and incubated at temperature of $28{ }^{\circ} \mathrm{C}$ for $24 \mathrm{~h}$ on a reciprocating shaker $(200$ cycles/min, Edmund Büchler SM-30 Control). In order to activate GlyDH, $1 \%$ [v/v] of the culture was transferred to an $150 \mathrm{~cm}^{3}$ activating medium that contained the following: yeast extract $5 \mathrm{~g} / \mathrm{L}$ (BTL), glycerol $20 \mathrm{~g} / \mathrm{L}(\mathrm{POCH})$ and $\left(\mathrm{NH}_{4}\right)_{2} \mathrm{SO}_{4} 5 \mathrm{~g} / \mathrm{L}(\mathrm{POCH})$, at $\mathrm{pH} 5.0$, and incubated at a temperature of $28{ }^{\circ} \mathrm{C}$ for $48 \mathrm{~h}$ on a reciprocating shaker (200 cycles/min, Edmund Büchler SM-30 Control).

\section{Obtention of a cell preparation with GlyDH activity}

On completion of the GlyDH-activating culture, the centrifuged biomass of $G$. oxydans $\left(5,000 \mathrm{~g}, 10 \mathrm{~min}, 4{ }^{\circ} \mathrm{C}\right.$, Eppendorf Centrifuge $5804 \mathrm{R}$ ) was double-rinsed with sterile distilled water and suspended in $60 \mathrm{~cm}^{3}$ of water. Afterwards, cells were disintegrated with the ultrasound method (sonication, $210 \mathrm{~W}, 18 \mathrm{kHz}, 4{ }^{\circ} \mathrm{C}, 5 \mathrm{~min}$, Omni Ruptor 4000, Titanium 3/8' Dia Solid OR-T-375), as a result of which a cell preparation with catalytic activity of 
GlyDH was obtained [19]. The cell sediment (partially purified from water-soluble proteins and small cellular organelles) and the supernatant were obtained after centrifugation $\left(9,500 \mathrm{~g}, 90 \mathrm{~min}, 4^{\circ} \mathrm{C}\right.$, Eppendorf Centrifuge 5804 R) of disintegrated G. oxydans cells [2, 3].

Immobilization of biocatalysts

The rinsed and centrifuged biomass of G. oxydans cells was suspended in $60 \mathrm{~cm}^{3}$ of a physiological saline solution and mixed with a sterile solution of sodium alginate $(40 \mathrm{~g} / \mathrm{L})($ Fluka) at the ratio of 1:1 [v/v]. From bacterial suspension in sodium alginate, gel beads of the same size were formed by direct instilling (using a syringe and a needle $0.9 \mathrm{~mm}$ in diameter) to a $0.2 \mathrm{M}$ solution of calcium chloride (II) (POCH). Next, the immobilizates were separated from the $\mathrm{CaCl}_{2}$ solution using a sterile aluminum sieve and rinsed with sterile distilled water $\left(500 \mathrm{~cm}^{3}\right)$. This procedure was applied to immobilize the cell preparation, the sediment and the supernatant.

\section{Biotransformation of glycerol to DHA}

Glycerol biotransformation to DHA was conducted using the following biocatalysts:

- Free or immobilized cells of $G$. oxydans in production media containing yeast extract $5 \mathrm{~g} / \mathrm{L}, \quad\left(\mathrm{NH}_{4}\right)_{2} \mathrm{SO}_{4}$ $7.5 \mathrm{~g} / \mathrm{L}$, glycerol $30 \mathrm{~g} / \mathrm{L}$, at $\mathrm{pH} 5.0$ and a temperature of $28{ }^{\circ} \mathrm{C}$,

- Immobilized cell preparation, sediment or supernatant in production solutions containing only glycerol at a concentration of $30 \mathrm{~g} / \mathrm{L}$ at $\mathrm{pH} 7.5$ and a temperature of $23{ }^{\circ} \mathrm{C}$.

Biotransformation was conducted in $150 \mathrm{~cm}^{3}$ of the culture medium or production solution, in flasks with a volume of $500 \mathrm{~cm}^{3}$ by reciprocating shaking (200 cycles/ min, Edmund Büchler SM-30 Control).

Determination of glycerol and dihydroxyacetone concentrations

Glycerol concentration was determined with the enzymatic method using a Free Glycerol Reagent test kit (Sigma, F6428) that contained a complex of enzymes catalyzing three reactions. In the first reaction, glycerol was phosphorylated and then glycerol 1-phosphate was oxidized. At the last stage, quinoneimine was produced, the pink-purple color of which was measured spectrophotometrically (BioRad Smart Spec 3000) at the wavelength of $540 \mathrm{~nm}$.

The concentration of DHA was assayed spectrophotometrically according to the method that uses the reducing properties of DHA [7]. To $2 \mathrm{~cm}^{3}$ of the analyzed sample,
$2 \mathrm{~cm}^{3}$ of 3,5-DNS acid was added and the sample was incubated at $100{ }^{\circ} \mathrm{C}$ for $10 \mathrm{~min}$. After incubation, the sample was immediately cooled. Its absorbance was measured at a wavelength of $550 \mathrm{~nm}$ (Bio-Rad Smart Spec 3000) against a blank sample, made of a sterile production media or of a production solution (depending on the biocatalyst applied).

\section{Calculation of reaction efficiency}

The efficiency of biotransformation was calculated from the equation of a chemical reaction of glycerol oxidation to DHA.

Statistical analysis of results

All analyses were carried out in three parallel series, with each of the series including three parallel biotransformations. Each measurement was repeated three times. Results achieved were developed statistically with the use of StatGraphicPlus 4.1 software. Multifactor analysis of variance was carried out as well. Significance of differences between mean values was determined with the Tukey's test at a significance level of $\alpha=0.01$.

\section{Results and discussion}

Biotransformation of glycerol to DHA with the use of free or immobilized cells of G. oxydans ATCC 621

The first stage of the study involved a series of biotransformations in production media with the use of free or immobilized cells of G. oxydans. The results are shown in Figs. 1 and 2.

The conducted study indicates that the course of glycerol biotransformation to DHA run with free or immobilized cells of G. oxydans was alike within the first $50 \mathrm{~h}$ (Fig. 1). The highest concentration of DHA noted for the free cells accounted for $25.8 \pm 0.023 \mathrm{~g} / \mathrm{L}$ after 4 days, whereas for the immobilized cells, it accounted for $24.6 \pm 0.032 \mathrm{~g} / \mathrm{L}$ after 3 days of the process. Glycerol was completely consumed from the production media (Fig. 1), but the efficiency of biotransformation did not reach $100 \%$ (Fig. 2), which suggests that part of the substrate could have been consumed for other reactions than oxidation to DHA. It pertains, in particular, to $G$. oxydans bacteria capability for glycerol transformation into sodium glycerate which is undetectable with the applied enzymatic method [14].

Despite achieving similar concentrations of DHA in particular hours of the biotransformation run in the presence of free or immobilized cells of G. oxydans (Fig. 1), 
Fig. 1 Changes in glycerol and DHA concentration during biotransformation run by free or immobilized cells of $G$. oxydans in production media at the initial glycerol concentration of $30 \mathrm{~g} / \mathrm{L}, \mathrm{pH} 5.0$ and temperature of $28{ }^{\circ} \mathrm{C}$

Fig. 2 Efficiency of biotransformation run by free or immobilized cells of $G$. oxydans in production media at the initial glycerol concentration of $30 \mathrm{~g} / \mathrm{L}, \mathrm{pH} 5.0$ and temperature of $28{ }^{\circ} \mathrm{C}$. Error bars added

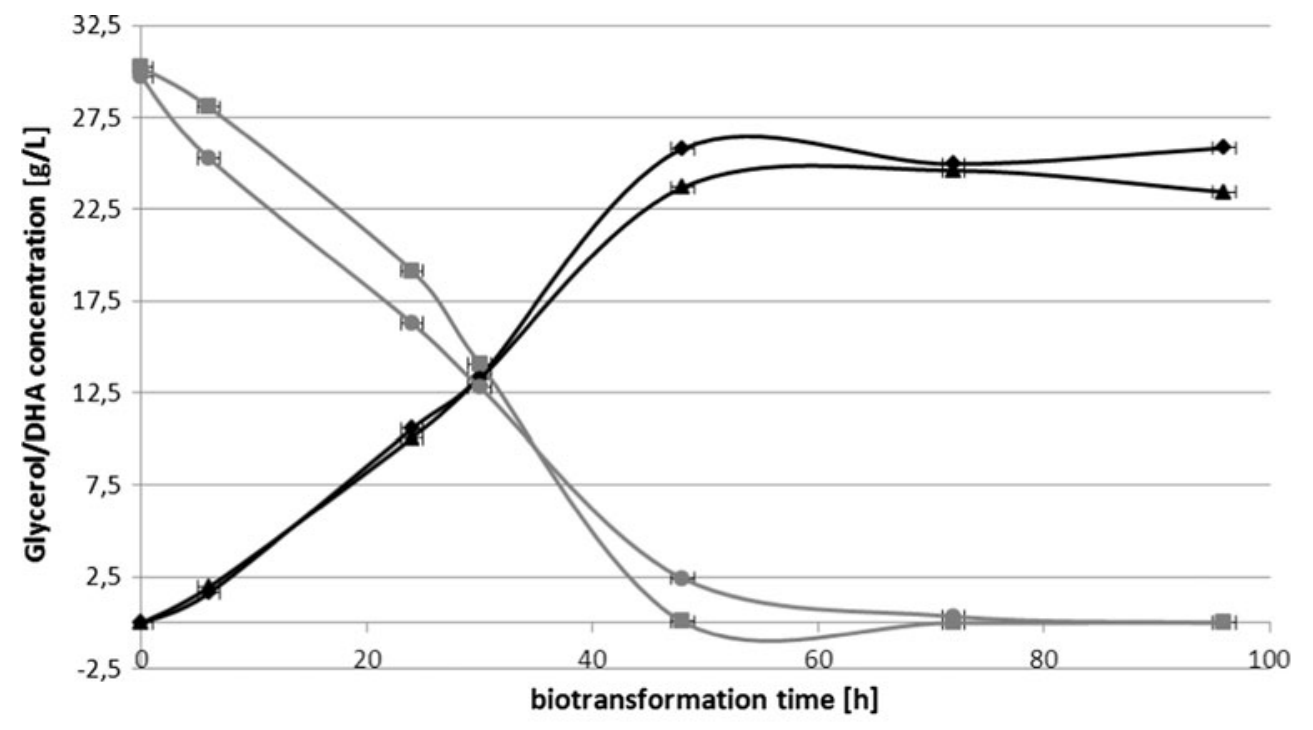

$\multimap$ DHA concentration for free cells

DHA concentration for immobilized cells

- - Glycerol concentration for free cells

$\multimap$ Glycerol concentration for immobilized cells

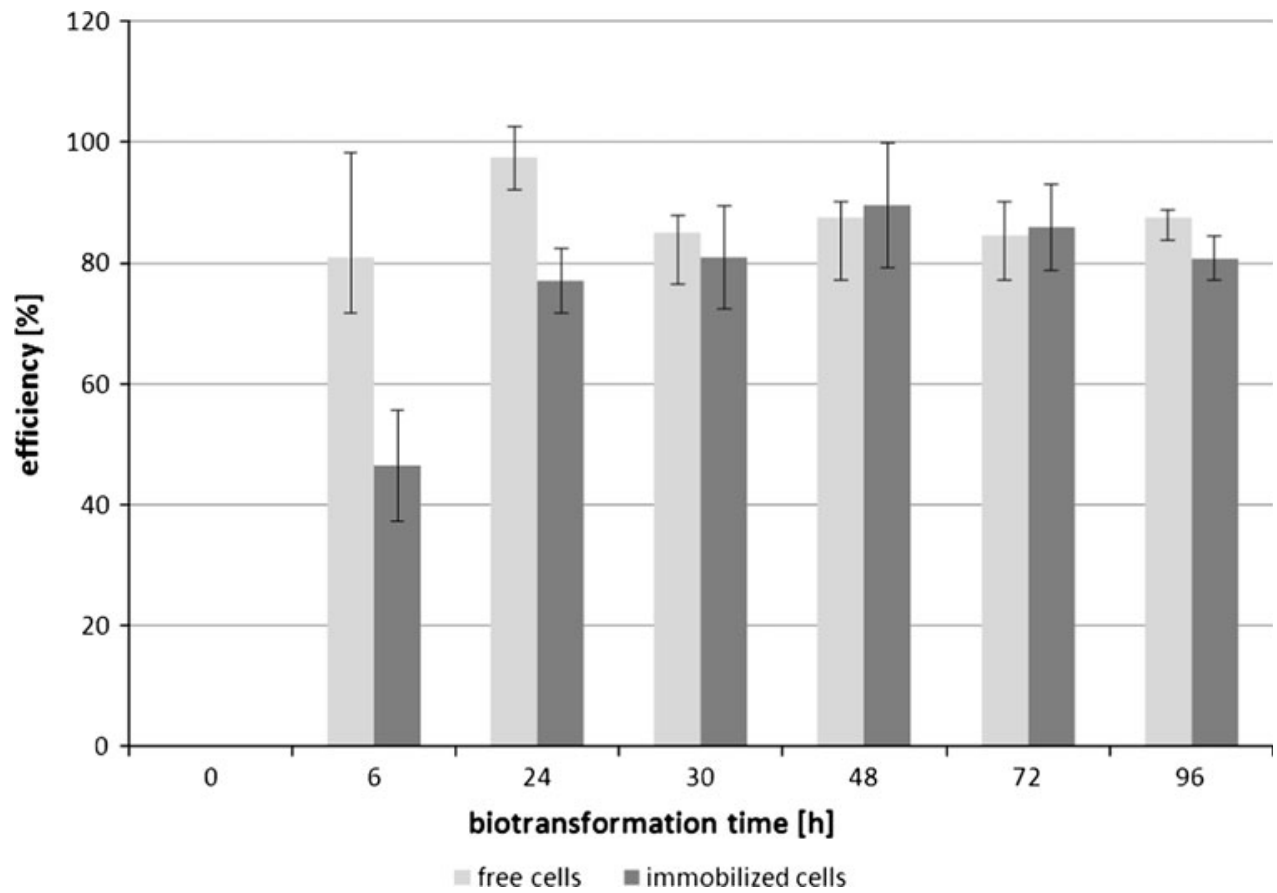

this process proceeded with the highest efficiency in the production medium with the free cells (Fig. 2). Probably, oxygen indispensable for glycerol oxidation into DHA was more easily available to the free than to the immobilized cells and the substrate was better utilized. The immobilization of bacterial cells in calcium alginate could, to some extent, limit oxygen and substrate diffusion to the interior and that of the product outside the alginate carrier.
On the second day of biotransformation, a significant increase was observed in DHA concentration in the production medium, irrespective of the biocatalyst applied (Fig. 1). The product's concentration in the medium with free cells increased from $0.16 \pm 0.051$ (in the 6th hour) to $10.5 \pm 0.027 \mathrm{~g} / \mathrm{L}$ (in the 24th hour), whereas in the production medium with immobilized cells from $0.19 \pm 0.070$ (in the 6th hour) to $10.1 \pm 0.020 \mathrm{~g} / \mathrm{L}$ (in the 24 th hour). 
This could be due to an increased activity of GlyDH, which in the case of the G. oxydans strain usually occurs after $20 \mathrm{~h}$ of biotransformation [4]. Oxygen concentration in that time could have been high enough to assure the effective course of glycerol oxidation to DHA, which was also pinpointed by Wethmar and Deckwer [35].

Biotransformation was finalized after 4 days because analyses of the production media revealed no presence of glycerol (Fig. 1). Due to a lack of carbon source in the medium, acetic acid bacteria may phosphorylate the earlier-produced dihydroxyacetone, and this leads to a reduction in the efficiency of the process [11].

The multifactor analysis of variance and Tukey's test conducted for values of DHA concentration achieved at this stage of the experiment demonstrated that reaction time was the only factor having a significant effect on increasing DHA concentration in the production media. The immobilization of $G$. oxydans cells did not affect the content of produced DHA compared to its concentration achieved with the participation of free cells.

Biotransformation of glycerol to DHA with the use of immobilized catalysts produced from $G$. oxydans cells

Literature data [20] indicate that GlyDH isolated from cytoplasmic membranes of $G$. oxydans bacteria showed a lower oxidative activity and stability compared to the fraction in which this enzyme remained bound with the membranes. For this reason, extraction and purification steps of GlyDH from cell organelles or fragments of cell membranes that were obtained upon ultrasound disintegration of $G$. oxydans cells were omitted deliberately.
Figures 3 and 4 show changes in concentrations of DHA and glycerol and in the efficiency of 5-day glycerol biotransformation run in an aqueous solution of this substrate, at a temperature of $23^{\circ} \mathrm{C}$ and $\mathrm{pH}$ 7.5.

After 24-h reaction run in the solution with the immobilized cell preparation, DHA concentration reached $6.1 \pm 0.020 \mathrm{~g} / \mathrm{L}$ (Fig. 3), whereas $22 \pm 0.079 \mathrm{~g}$ of glyc$\mathrm{erol} / \mathrm{L}$ was still left in the solution (Fig. 3) and the efficiency of reaction reached $76 \%$ (Fig. 4). On the next day, DHA concentration reached $12.4 \pm 0.041 \mathrm{~g} / \mathrm{L}$ of the production solution (Fig. 3) at the reaction efficiency of $88 \%$ (Fig. 4). After 5 days of the process, the concentration of dihydroxyacetone accounted for $26.1 \pm 0.021 \mathrm{~g} / \mathrm{L}$ of the solution (Fig. 3), the reaction efficiency was at a level of $88 \%$ (Fig. 4), and glycerol was almost completely consumed from the production solution (Fig. 3). As initially expected, the course of changes in concentrations of DHA and glycerol in production solutions with the immobilized sediment was similar to that of changes observed in the process run with the cell preparation (Fig. 3). The supernatant was devoid of the catalytic activity of GlyDH because no DHA was detected in the solution with this biocatalyst (Fig. 3). This experiment confirmed that GlyDH remained bound with fragments of cellular membranes of G. oxydans (present in the cell preparation and in the sediment) and after disintegration was not released to the fraction of water-soluble proteins (present in the supernatant).

In biotransformation run with the cell preparation or the sediment, glycerol was completely consumed from the solutions (Fig. 3), but still the reaction efficiency did not reach $100 \%$ (Fig. 4). It may be speculated that part of the DHA remained trapped in the structure of an alginate
Fig. 3 Changes in concentrations of glycerol and DHA during biotransformation run by the immobilized cell preparation, sediment or supernatant in production solution with the initial glycerol concentration of $30 \mathrm{~g} / \mathrm{L}$, at $\mathrm{pH}$ 7.5 and a temperature of $23^{\circ} \mathrm{C}$

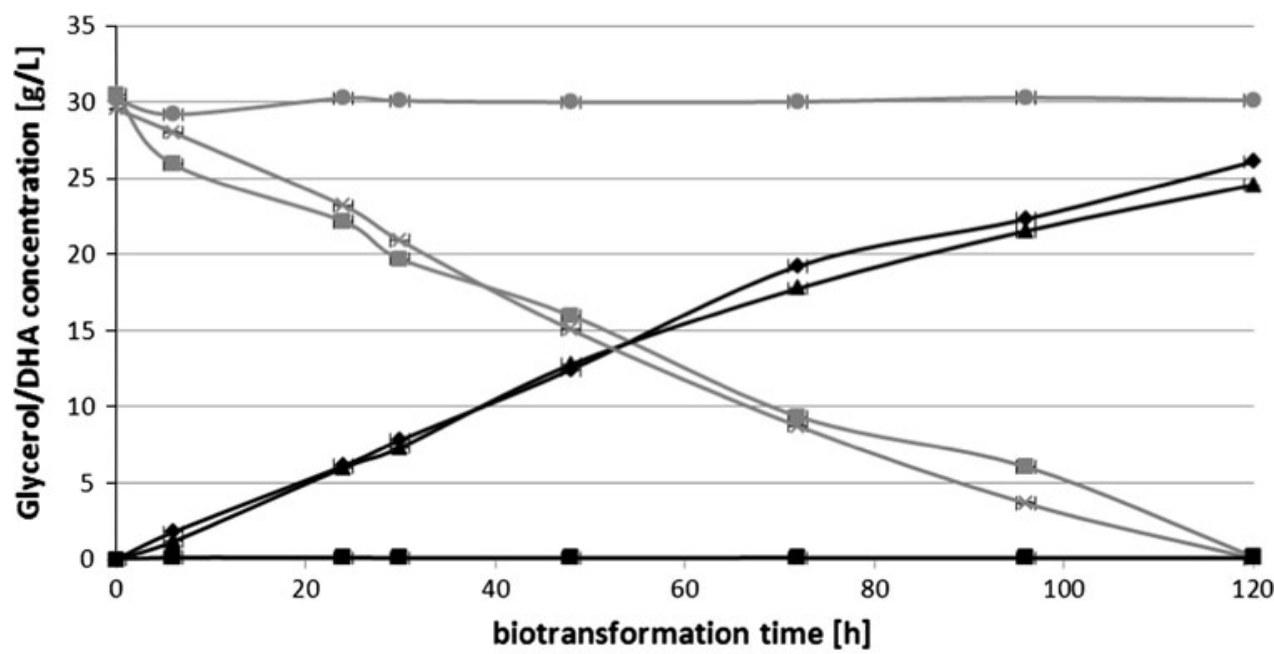

- - Glycerol concentration for cell preparation $\ldots$ Glycerol concentration for sediment $\multimap$ Glycerol concentration for supernatant 
Fig. 4 Efficiency of biotransformation run by the immobilized cell preparation, sediment or supernatant in production solution with the initial glycerol concentration of $30 \mathrm{~g} / \mathrm{L}$, at $\mathrm{pH} 7.5$ and a temperature of $23{ }^{\circ} \mathrm{C}$. Error bars added

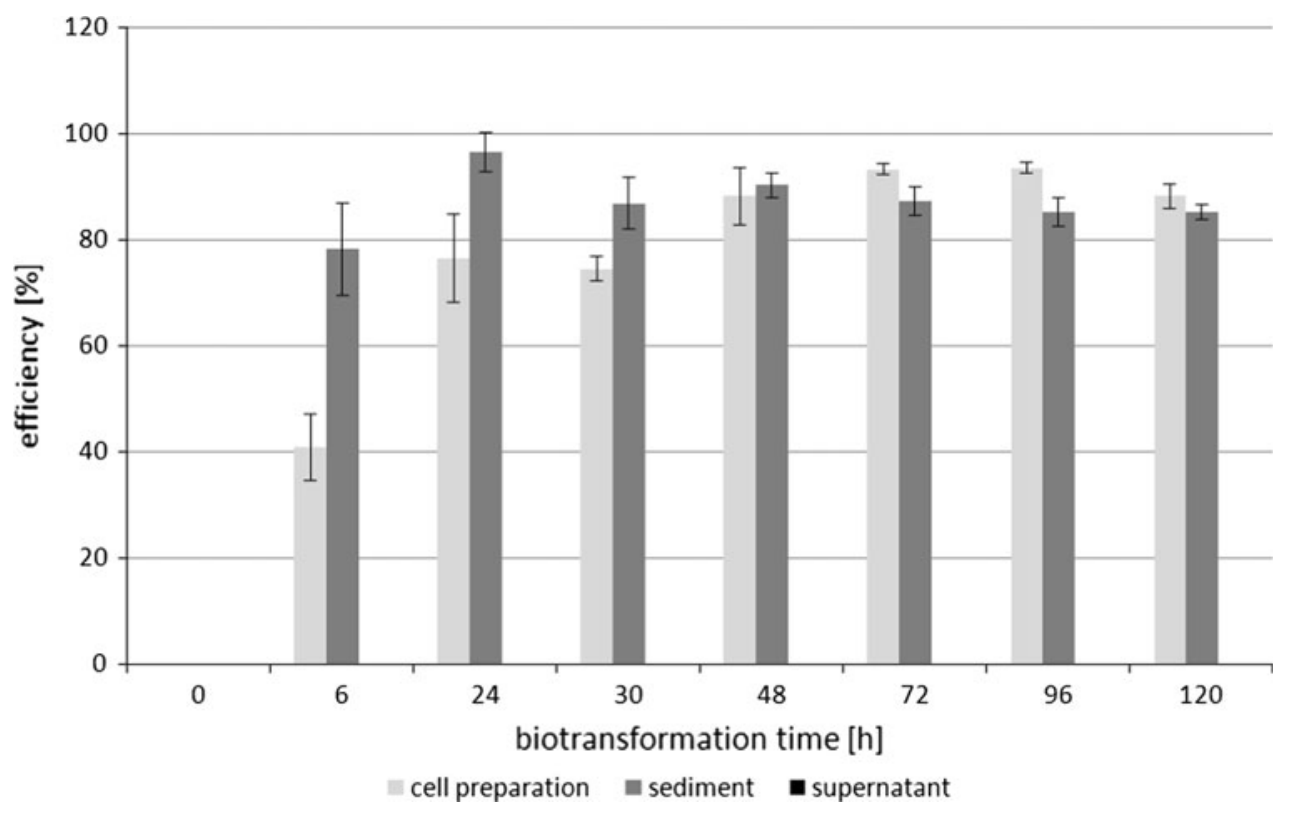

carrier and could not be released to the solution and determined with the method applied.

The highest concentrations of DHA achieved in reaction run with the free $(25.8 \pm 0.023 \mathrm{~g} / \mathrm{L})$ or immobilized cells $(24.6 \pm 0.032 \mathrm{~g} / \mathrm{L})$ of $G$. oxydans (Fig. 1) were similar to concentrations reported in the reactions with the immobilized cell preparation $(26.1 \pm 0.021 \mathrm{~g} / \mathrm{L})$ or the sediment $(24.6 \pm 0.009 \mathrm{~g} / \mathrm{L})$ (Fig. 3). These results enable concluding explicitly that the cell preparation had the catalytic activity of GlyDH that was comparable to the activity exhibited by live G. oxydans cells. The conducted study demonstrated the feasibility of producing DHA via oxidation of an aqueous solution of glycerol in the presence of an immobilized cell preparation from G. oxydans.

Evaluation of the oxidative potential of reused cell preparation

The purpose of successive biotransformation series was to verify whether the immobilized cell preparation applied in one biotransformation cycle maintains its GlyDH activity in the next cycle. On completion of 7-day biotransformation, the immobilized cell preparation was rinsed with sterile distilled water cooled to $4{ }^{\circ} \mathrm{C}$ and again transferred into the production solution with glycerol concentration of $30 \mathrm{~g} / \mathrm{L}$. Simultaneous biotransformation was run with a cell preparation that was not applied earlier for glycerol oxidation to DHA. Results of these analyses were presented in Figs. 5 and 6.

In the solution with the cell preparation used for the first time, the concentration of DHA accounted for $9.2 \pm$ $0.030 \mathrm{~g} / \mathrm{L}$ after the first day, for $24.4 \pm 0.003 \mathrm{~g} / \mathrm{L}$ after
4 days and for $27.2 \pm 0.001 \mathrm{~g} / \mathrm{L}$ after 7 days of the process (Fig. 5). The efficiency of reaction in those periods reached 44, 84 and $94 \%$, respectively (Fig. 6). In the said solution, glycerol was utilized almost completely (Fig. 5). The low final concentration of the substrate $(0.09 \pm$ $0.010 \mathrm{~g} / \mathrm{L}$ ) and, simultaneously, a high reaction efficiency reaching $94 \%$ (Fig. 6) enable concluding that glycerol was almost completely oxidized to dihydroxyacetone.

The reused cell preparation was not so efficient in running glycerol biotransformation to DHA. The highest concentration of dihydroxyacetone, noted after 3 days of the reaction, reached $16.1 \pm 0.004 \mathrm{~g} / \mathrm{L}$ (Fig. 5). Although the reaction efficiency accounted for $94 \%$ (Fig. 6), $12.2 \pm 0.019 \mathrm{~g}$ of glycerol/L was still left in the solution (Fig. 5). The extension of biotransformation time did not cause an increase in product's concentration (Fig. 5). The content of glycerol in the solution was not changing since the 3rd day till the end of the process.

Glycerol dehydrogenase is an enzyme-dependent PQQ prosthetic group [4, 27]. It is likely that during the first application of the cell preparation, GlyDH contained in it bounded a sufficiently high concentration of PQQ from G. oxydans cell and could run efficient oxidation of the substrate. Probably, the concentration of PQQ in the reused cell preparation was not high enough, which might have had a negative impact on the course and efficiency of glycerol biotransformation to DHA.

Similar investigations with cells of G. oxydans immobilized in polyvinyl alcohol gel were carried out by Wei et al. [33]. The efficient production of DHA from glycerol proceeded at $\mathrm{pH} 6.0$ and a temperature of $30{ }^{\circ} \mathrm{C}$. Such cells displayed the oxidative activity against glycerol even after 
Fig. 5 Changes in

concentrations of glycerol and DHA during biotransformation run by immobilized cell preparations in production solutions with initial glycerol concentration of $30 \mathrm{~g} / \mathrm{L}$, at $\mathrm{pH}$ 7.5 and a temperature of $23{ }^{\circ} \mathrm{C}$

Fig. 6 Yield of biotransformation run by immobilized cell preparations in production solutions with initial glycerol concentration of $30 \mathrm{~g} / \mathrm{L}$, at $\mathrm{pH}$ 7.5. Error bars added

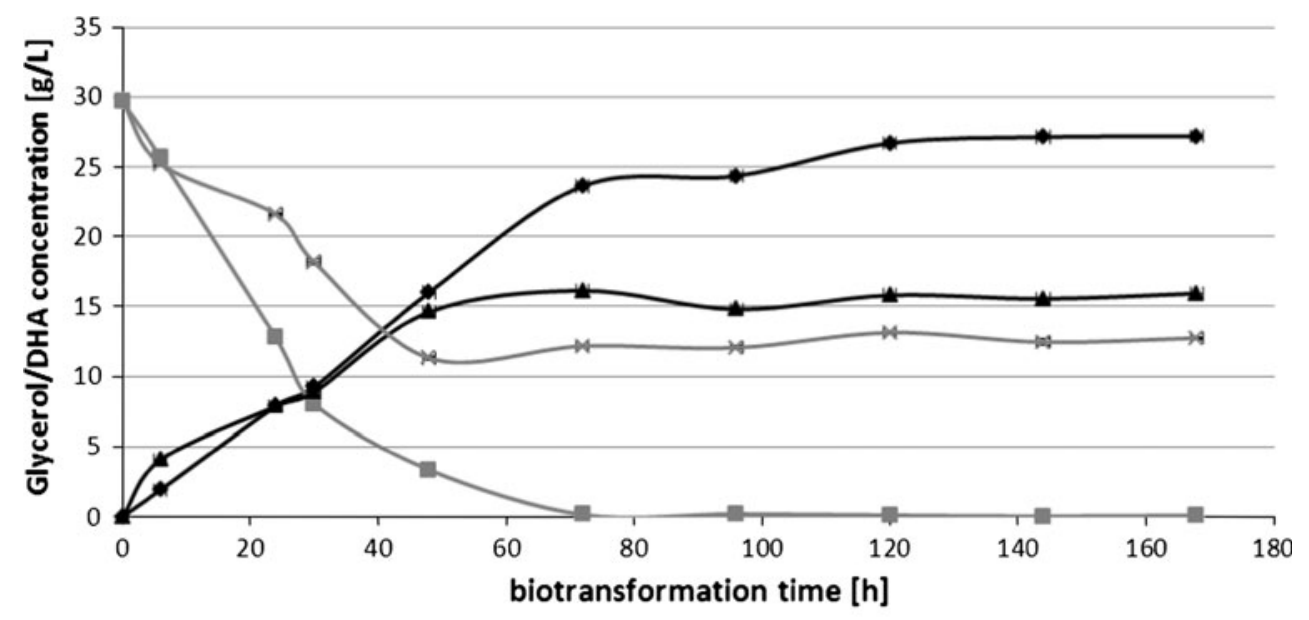

$\rightarrow$ DHA concentration for cell preparation

$\rightarrow-$ Glycerol concentration for cell preparation

$\leftarrow$ DHA concentration for reused cell preparation

-Glycerol concentration for reused cell preparation

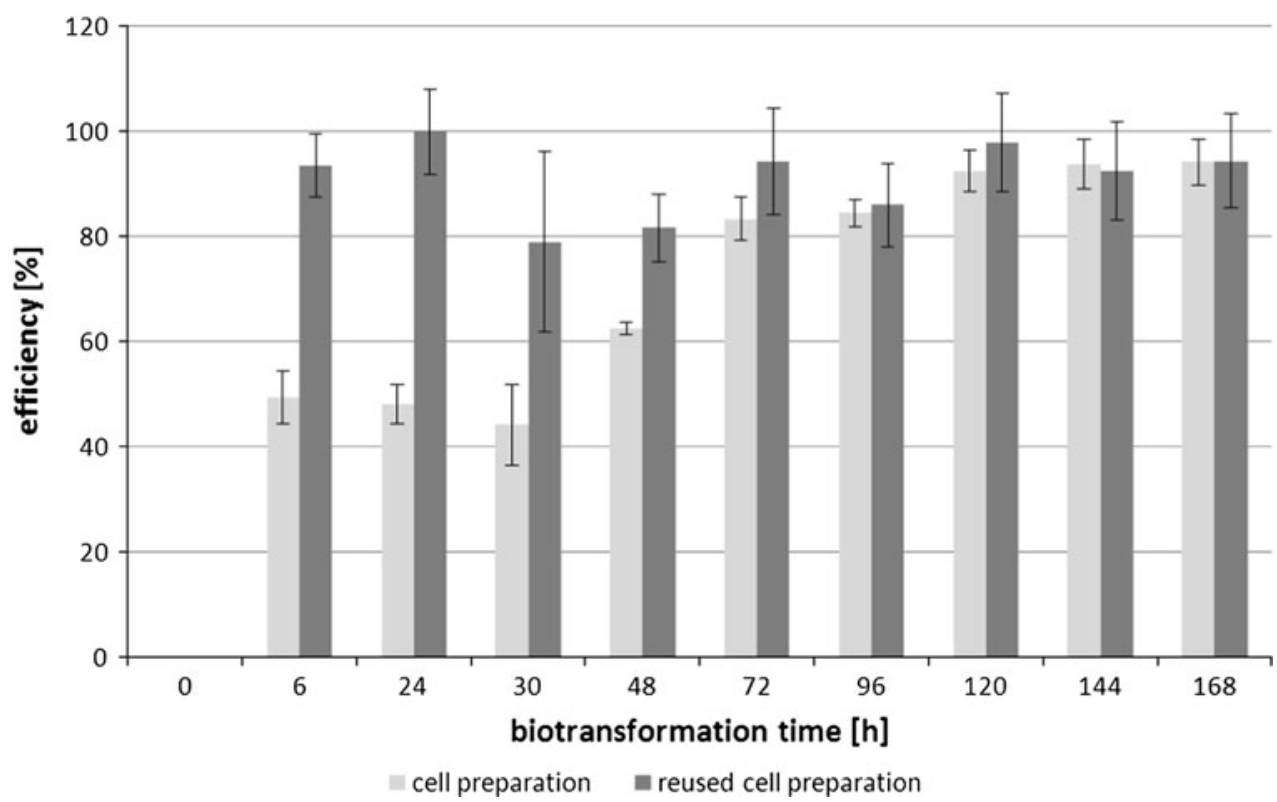

14 days of storage; however, the activity was lower by $10 \%$ than that of the cells applied immediately after immobilization. The immobilized cells of $G$. oxydans bacteria reused in the reaction medium were running the biotransformation process with the efficiency about $86 \%$ [33].

Studies on the oxidation of glycerol to DHA with the use of live G. oxydans cells are mainly focused on reducing production costs, facilitating the process and reaching possibly the highest reaction efficiency [18]. Therefore, the application of the immobilized cell preparation for the biotransformation process may be an interesting alternative to the traditional method of DHA synthesis.

\section{Conclusions}

The study was aimed at elaborating a new biotechnological method for the production of dihydroxyacetone via oxidation of a glycerol solution with the use of an immobilized cell preparation produced from acetic acid bacteria G. oxydans ATCC 621. Problems associated with traditional production of DHA based on living cells were supposed to be reduced or eliminated by making biotransformation independent of the metabolic activity of live $G$. oxydans cells and by replacing microbiological culture media with aqueous solutions of glycerol at a concentration of $30 \mathrm{~g} / \mathrm{L}$. The proposed method of glycerol 
biotransformation to DHA run in a $3 \%$ aqueous solution of substrate with $\mathrm{pH} 7.5$, at a temperature of $23{ }^{\circ} \mathrm{C}$, allowed to obtain $27.2 \mathrm{~g} \mathrm{DHA} / \mathrm{L}$ of the solution with $94 \%$ efficiency of the reaction. The free or immobilized cells of G. oxydans, placed in the production medium that apart from nutrients and minerals contained $3 \%$ of glycerol, at $\mathrm{pH} 5.0$ and a temperature of $28^{\circ} \mathrm{C}$, produced about $25 \mathrm{~g}$ DHA/L of the medium at a reaction efficiency of $87 \%$.

This study proved that efficient biotransformation of glycerol to DHA with the use of a cell preparation could proceed in an aqueous solution of the substrate. Analytical results achieved point to the feasibility of making DHA production independent of the presence of viable $G$. oxydans cells. The application of the novel method for DHA production will, probably, eliminate the multistage purification of the final product. Immobilization of the cell preparation with GlyDH activity will facilitate the procedure of DHA production, as the biological material entrapped in carrier's structure may easily be separated from the post-production solution.

Open Access This article is distributed under the terms of the Creative Commons Attribution License which permits any use, distribution, and reproduction in any medium, provided the original author(s) and the source are credited.

\section{References}

1. Adachi O, Matsushita K (1997) USA Patent nr 56143774

2. Adlercreutz P, Holst O, Mattiasson B (1985) Appl Microbiol Biotechnol 22:1-7

3. Alberts B, Bray D, Johnson A, Lewis J, Raff M, Roberts K, Walter P (1999) PWN, Warsaw pp 155-172

4. Ameyama M, Shinagawa E, Matasushita K, Adachi O (1985) Agric Biol Chem 49:1001-1010

5. Bicker M, Endres S, Ott L, Vogel H (2005) J Mol Catal A Chem 239:151-157

6. Charney W, Montclair NJ (1978) USA Patent nr 4076589

7. Chen J, Chen J, Zhou C (2008) J Chromatogr Sci 46:912-916

8. Choquenet B, Couteau C, Paparis E, Coiffard LJM (2009) J Dermatol 36:587-591

9. Claret C, Bories A, Soucaille P (1992) Current Microbiol 25:149-155
10. Enders D, Voith M, Lenzen A (2005) Angew Chem Int Ed 44:1304-1325

11. Erni B, Siebold C, Christen S, Srinivas A, Oberholzer A, Baumann U (2006) Cell Mol Life Sci 63:890-900

12. Gätgens C, Degner U, Bringer-Meyer S, Herrmann U (2007) Appl Microbiol Biotechnol 76:553-559

13. Gehrer E, Harder W, Vogel H, Knuth B, Ebel K, Groening C (1995) USA Patent nr 5410089

14. Gupta A, Singh VK, Qazi GN, Kumar A (2001) J Mol Microbiol Biotechnol 3:445-456

15. Hekmat D, Bauer R, Neff V (2007) Proc Biochem 42:71-76

16. Hekmat D, Bauer R, Fricke J (2003) Bioproc Biosyst Eng 26:109-113

17. Henderson PW, Kadouch D, Singh SP, Zawaneh PN, Weiser J, Yazdi S, Weinstein A, Krotscheck U, Wechsler B, Putnam D, Spector JAJ (2010) Biomed Mater Res A 93:776-782

18. Hu ZC, Zheng YG, Shen YC (2011) Bios Technol 102:7177-7182

19. Kapucu H, Gülsoy N, Mehmetoğlu Ü (2000) Biochem Eng J 5:57-62

20. Lapenaite I, Kurtinaitiene B, Razumiene J, Laurinavicius V, Marcinkeviciene L, Bachmatova I, Meskys R, Ramanavicius A (2005) Anal Chem Act 549:140-150

21. Li M, Wu J, Liu X, Lin J, Wei D, Chen H (2010) Biores Technol 101:8294-8299

22. Ma L, Lu W, Xia Z, Wen J (2010) Biochem Eng J 49:61-67

23. Matsushita K, Fujii Y, Ano Y, Toyama H, Shinjoh M, Tomiyama N, Miyazaki T, Sugisawa T, Hoshino T, Adachi O (2003) Appl Environ Microbiol 69:1959-1966

24. Mishra R, Jain SR, Kumar A (2008) Biotechnol Adv 26:293-303

25. Nguyen HTT, Nevoigt E (2009) Metabol Eng 11:335-346

26. Obeid OA, Jamal ZM, Hwalla N, Emery PW (2006) Nutrition 22:794-801

27. Oubrie A, Dijkstra BW (2000) Protein Sci 9:1265-1273

28. Painter RM, Pearson DM, Waymonth RM (2010) Angew Chem Int Ed 49:9456-9945

29. Prust Ch, Hoffmeister M, Liesegang H, Wiezer A, Fricke WF, Ehrenreich A, Gottschalk G, Deppenmeier U (2005) Nat Biotechnol 23:195-200

30. Rogers CJ (2005) Aesth Surg J 25:413-415

31. Schmid D, Belser E, Zulli F (2007) Cosmet Toilet 6:55-60

32. VanLare IJ, Claus GW (2007) Can J Microbiol 53:504-508

33. Wei S, Song Q, Wei D (2007) Prep Biochem Biotechnol 37:67-76

34. Weiser JR, Zawaneh PN, Putnam D (2011) Biomacromolecule 12:977-986

35. Wethmar M, Deckwer WD (1999) Biotechnol Tech 13:283-287

36. Xu X, Chen X, Jin M, Wu X, Wang X (2009) Chin J Biotechnol 25:903-908 